\title{
Okçuluk Risalesi*
}

\section{Resāle-Ye Kamān-Dārī}

\section{Kepûr Çend Neşr. İrec AFŞÂR / Çeviri: İbrahim DUMAN ${ }^{1}$ C]}

* Neşredilen bu okçuluk risalesinin künyes şöyledir: Kepûr Çend, "Risâle-yi Kemân-dârî", neşr. İec Afşâr, Ber-resîhâ-yi Târîhî, XIV, (1347/1968), s. 75-88. Köşeli parantez ve normal parantez içindeki kelimeler ile bu yazıdaki bütün dipnotlar, anlam bütünlüğünü sağlamak adına mütercimin eklemesidir.

'Sorumlu yazar/Corresponding author: İbrahim DUMAN (Dr.),

İstanbul, Türkiye

E-posta: dumanlee41@gmail.com

ORCID: 0000-0002-1454-3052

Başvuru/Submitted: 16.10 .2019 Revizyon Talebi/Revision Requested: 31.10 .2019

Son Revizyon/Last Revision Received: 04.11.2019

Kabul/Accepted: 05.11.2019

Atıf/Citation: Cend, Kepur / Ceviri İbrahim Duman. "Okçuluk Risalesi." Şarkiyat Mecmuası Journal of Oriental Studies 35 (2019), 59-70. https://doi.org/10.26650/jos.2019.011

\section{Öz}

Tarihte ok ve yayın ilk olarak hangi coğrafyada kullanıldığı bilinmemektedir. Bununla birlikte okçuluk dünyanın birçok yerinde eski devirlerden itibaren uygulanmıştır. Her coğrafyanın kendine has olan okçuluk tarzı tarihin derinliklerinden gelmektedir. Yüzyıllar boyu oluşan bu kültürü gelecek kuşaklara aktarmak için eserler yazılmıştır. Okçuluk risaleleri, geçmişte okçuluğun nasıl icra edildiği, püf noktalarının neler olduğu, ok ve yayın hangi maddelerden üretildiği, okçunun karakterinin nasıl olması gerektiği gibi muhtelif konularda gelecek kuşaklara bilgi aktarımı yapmak için kaleme alınmış eserlerdir. Bu çeviride İrec Afşâr tarafından neşredilen bir okçuluk risalesi, Farsçadan Türkçeye tercüme edilmiştir. Hint-Pers kültür sahasına ait bu eserin okçuluk, silâh ve kültür tarihi için mühim bilgilere sahip olduğu düşünülmektedir.

Anahtar kelimeler: Okçuluk, Ok, Yay, Silâh, İran

\section{ABSTRACT}

In history, it is not known in which geography the bow and the arrow were used for the first of all. However, archery has been practiced in many parts of the world since ancient times. The unique archery style of each geography comes from the depths of history. Booklets were written to transfer this culture, which has been formed over the centuries, to the next generations. Archery booklets are works, that are written to transfer information to the next generations on various subjects such as how archery was performed in the past, what the tricks are in archery, what materials the arrow and the bow are made of, and how the character of the archer should be. In this translation, an archery booklet, that was published by Iraj Afshār, has been translated from Persian to Turkish. This booklet, which belongs to the Indo-Persian cultural area, is thought to have important information for the archery, arms and cultural history.

Keywords: Archery, Arrow, Bow, Arms, Iran 


\section{Nâşirin (İrec Afşâr'ın) Mukaddimesi}

Yay sahibi olmak ve okçuluk, bir zamanlar ateşli silâhları özellikle tüfek kullanmayı gelenek hâline getirmemiş kavimlerde sporla ilgili sanatların ve yiğitliklerin bir göstergesiydi. Süvarilerin ve savaşçıların kendi ülke ve sınırlarını müdafaa etmek için öğrendikleri bir sanattı. Gençlerin ve yiğitlerin onun eğlence ve sanatsal yönünü güzel şekilde icra ettikleri bir uğraşıydı.

Okçuluk, yay imâli ve onun gereçleri hakkında Farsça birçok risale telif edilmiştir. Muhammed Takî Dânişpejûh, hicrî 718 senesinde Şucâ'u'd-dîn Dorûd-bâş̧îyi Beyhakî adıyla bilinen Nizâmu'd-dîn Ahmed b. Muhammed b. Ahmed tarafından yazılan Câmi'u'l-Hidâyet fì 'İlmi'r-Rimâyet isimli' ${ }^{1}$ Farsça okçuluk risalesinin önsözünde yirmi dört okçuluk risalesini tanıtmıştır.

Şimdi bu sayfalarda yer alan risale, Sayın Hasan-'Alî-yi Gaffârî (Mu'âvinu'd-devle)'nin kendi kitaplarıyla birlikte Üniversite Merkez Kütüphanesi’ne ${ }^{2}$ hediye ettiği bir mecmuanın parçasıdır. Bu mecmua, çeşitli yazıların bulunduğu on risaleden ibarettir. Bu risalelerden birisi, Intihâb-i Risâle-yi Kavsiye-yi Tasnîf-i Kepûr-Çend'dir. Risale, Hint şehirlerinden birinde yazılmıştır. Kısacası okçuluk terimleri bakımından çok faydalıdır.

Bu günlerde faziletli, muhterem Ahmed Suheylî-yi Hânsârî, Fahr-i Mudebbîr'in bu zamana kadar neşredilmemiş olan Âdâbu'l-Harb ve 'ş-Şecâ'a kitabını yayımlamayı başardı ${ }^{3}$. Bu kitap, eski savaşlarda kullanılmış olan ve tarihî araştırma için önemi bulunan çeşitli silâhlar hakkında birçok bölümü kapsamaktadır. Mezkûr kitabın basılması hakkında Hânsârî’nin çabası takdir edilmelidir. Her ne kadar bilinmeyen ve meçhul olan kelimeler ile terimlerin çokluğu, araştırma ve incelemeye muhtaç bulunsa da sözlük ve tarih uzmanları için değerli olan bir işi halletmiştir.

\section{Bismillahirrahmannirrahîm}

Muteber okçuluk kitaplarında bu ilmi (okçuluğu) öğrenenin vasıflarını şu sıfatlar ile ayrıntılı bir şekilde yazmışlar:

Birincisi; iyi karakter [sahibi olmak].

İkincisi; adaletli usta (hoca) [ile çalışmak].

Üçüncüsü; tamahkâr olmayan temiz hayat [sahibi olmak].

Dördüncüsü; doğru söz ve davranış [sahibi olmak].

Beşincisi; iyi huylu ve boylu poslu [olmak].

Altıncısı; sıkıntıya katlanan ve yiğit [olmak].

Yedincisi; geniş göğüslü ve omuzlu [olmak].

1 Neşredilen bu okçuluk risalesinin künyesi şöyledir. Şucâ'u'd-dîn Dorûd-bâşîyi Beyhakî, "Câmi'u'l-Hidâyet fî 'İlmi'r-Rimâyet”, neşr. Muhammed Takî Dânişpejûh, Ferheng-i İrân-zemîn, XI, (1342/1963), s. 229-280. Bu risale Türkçeye tercüme edilmiştir: Okçuluk Sanatı, Türkçe terc. İbrahim Duman, İstanbul 2020.

2 Tahran Üniversitesi Merkez Kütüphanesi.

3 Delhi Türk Sultanlığı zamanında (1206-1526) yaşamış olan Fahr-i Mudebbîr' in Âdâbu 'l-Harb ve 'ş-Şecâ 'a isimli eseri Ortaçağ savaş tarihi bakımından çok önemlidir. Eserin künyesi şöyledir: Fahr-i Mudebbîr, Âdâbu'l-Harb ve'ş-Şecâ'a, neşr. Ahmed Suheylî-yi Hânsârî, Tahran 1346/1967. 
Sekizincisi; insanlara eziyet eden, zalim olmamak.

Dokuzuncusu; az uyuşuk ve çok itaatkâr (ibadet eden) [olmak].

Onuncusu; uzun el ve kanaat sahibi [olmak] ve nankörlüğü, cimriliği, kötülük yapmayı, asık suratı, aşağılamayı bu ilimde (okçulukta) uygun görmemişler.

Kutlu düşünceye sahip olan her mutluluğun iç yüzünde, bu methedilmiş yöntem (tarz) akla gelir. [Bunun için] ilk olarak ustanın elinden temiz yürek ve istek ile kabza almayı (تمام قبضه) elde etmek, okçuluğa başlamayı gösterir.

\section{Şiir}

Ustadan kabza almak lazım,

Doğru hedefe bakış ile kabza tutmak için.

Okçu, devamlı temiz olmalıdır (abdest almalıdır). Temizlenmeden (abdest almadan) oka, yaya ve okçuluk âletlerine el sürmemelidir. Nerede ok atılırsa atılsın, okçulukta süreklilik gerekir.

\section{Şiir}

Başparmağı ve kabzayı doğrulttuğunda [oku] çek ve at,

Gündüz ok firlat, gece de.

[Okçu] asla bu kapıda (burada) tembelliği düşünmez. Ustalar, bir gün [dahi] ok atmak terk edilirse, kırk gün aralıksız ok atılmasını, [böylece] eksikliğin telafi edilmesini ve ilk hâle geri dönülmesi gerektiğini söylemişler.

[Atıc1], okunu ve yayını daima sağlıklı eliyle tutar. [Bu suretle] iş vaktinde, meclis ve savaş meydanında (veya gösteri yerinde) hünerini icra edebilir. Asla ödünç ok ve yay ile okçuluk yapmaz.

\section{Şiir}

Seçkin ok ve yay, sağlıklı elin bekçisi,

Öyle ki savaş meydanında sevdalının yanı bahane,

Ödünç elbise içinde arar kendi yüce namını,

Yani ok ve yay da ister insan gibi.

Yay imâli çok dikkat ve incelik gerektiren bir iştir. [Yaylar] her zaman türlü ebatlarda yapılmışlar ki onların (eski okçuların) yayının ölçüsü 6,5 karış ${ }^{4}$ imiş. Ustalar bu zamanda da bir yayı uygun esneklik derecesi ile birlikte benzer ölçüde yaparlar. Bu yüzden yay, yapılmasını söyledikleri ebatta olmalıdır. [Yay imâlinde] genç hayvan boynuzu, dut ağacı ahşabı, tutkal ve

4 Karış, gerilen elin başparmak ile serçe parmağı arasındaki uzaklıktır. 
iyi sinir kullanılır. Yayın iki kasanı (خانه كمان) bir boynuz ve ahşaptan yapılır. Yontma ve son törpü (veya uç törpüsü) ihtiyatla icra edilir. [Yontma ve törpüleme] şöyle yapılır: Eğer yayı kabzadan bir ip ile asarlarsa, yayın iki kasanı, iki terazi kefesi gibi eşit durur. Bir kasanın ağırlığı, diğer kasanın ağırlığından az veya çok olmaz. [Yayı] çok kurutmak ve yağlamak makbuldür.

[Yayı] hangi ustanın yaptığını anlamanın ipuçları şunlardır: Yayı başlangıçta çekmenin zorluğu, sonrasında yayın beğenilmesi, zarif görünümü, hafifliği ve keskin sesidir.

Yayın kusurları; gereğinden uzun veya kısa olması, kabzasının çok kalın, ince veya yumuşak olmasidir.

Eğer yayın başı neresidir diye sorarlarsa, okun kabzadan dışarı çıktığı yeri' ${ }^{6}$ cevap olarak söyle!

Yayın ihtiyacı kiriştir. Kasanın ihtiyacı yeni oktur. Kendi hâline bırakılan (hedefe gönderilen) okun, yay ve kasana zarar vermesi mümkün değildir.

\section{Misra}

Kötü kiriş, yaya halel getirir.

Kiriş teli pürüzsüz olmalı ve ortasında büklüm olmayacak şekilde bağlanmalıdır. Kirişin halkaları gevşek olmalı ve sağlam düğümlenmelidir. [Kirişin] kalınlığı ve inceliği, yayın baskı ölçüsünden çok olmamalıdır. Eğer kiriş kalın olursa, yay kiriş sesinden dolayı gücünü kaybeder ve ok yavaş gider. Eğer kiriş ince olursa, [baskı karşısında] kopması mümkündür. [Ancak ustalar] kiriş, yayın baskısına uygunsa biraz ince olabileceği konusunda mutabık kalmışlar. [Bu durum] okun, başparmaktan çevik bir şekilde çıkması ve veriminin çoğalması için daha iyidir. Sonunda okçu kendi yay kirişini yeni tutar. Çünkü kiriş, çille (جله) (ج) $)^{7}$ olarak bilinir. Kırk günden fazla korunamaz. Eğer [kirişten] fazla ok atılmışsa, [kirişi] kırk güne kalmadan değiştirmek gerekir. [Bununla birlikte] ustalardan bazıları kırk gün sonrasında ok atmanın yeni kirişi sağlamlaştırdığını abartılı olarak söylemişler. [Bu durum için] kirişin uzunluğu ve kısalığı önem arz etmez.

Kirişin ortasına meydân (ميدان) derler. [Kiriş] sıkıca bağlanır ve kirişin sesinin tok (ağır) çıkmaması için fazla mum sürülmez.

Savaş günü ve av esnasında yanında birkaç kiriş bulundurmak, yapılması gerekenlerdendir.

\section{Ok Yapımı ve Tanımı ile Okun Kusur ve Hünerlerini Anlamak Hakkında}

Eğer kamış, tüy ve temrenin ok olmak için nasıl bir araya geldiğini sorarlarsa, [şöyle] cevap ver: Eğer kamış ince olursa, temren hafif [bir şekilde] yerleştirilirse ve tüy, oku etkilemeyecek şekilde uygun olursa, [oku] sinama mümkündür.

5 Fars okçuluk literatüründe hâne-yi kemân (خانه كمان) terimi yayın kasan bölümünü belirtir. Yayın kısımları hakkında ayrıntılı bilgi için bkz. Ünsal Yücel, Türk Okçuluğu, Ankara 1999, s. 263-264; Adam Karpowicz, Osmanlı Türk Yayları İmali ve Tasarım, Türkçe terc. Mehmet Yılmaz Akbulut, İstanbul 2018, s. 51.

6 Bu yere tîr geçimi denir. Daha fazla bilgi için bkz. Ünsal Yücel, Türk Okçuluğu, s. 262.

7 Çille, Farsça çihil yani kırk kelimesinden gelir. Osmanlı yay kirişlerine de çile denirdi. Bkz. Ünsal Yücel, Türk Okçuluğu, s. 268-269; Adam Karpowicz, Osmanlı Türk Yayları İmali ve Tasarım, s. 167. 
Eğer kamış ağır ve temren büyük ise, tüyler eşit ağırlıkta olmalıdır. Eğer ok tüyünün uzunluğunun (nereye kadar olduğunu) sorarlarsa, kabzanın ölçüsünü (uzunluğunu) geçmemesi [gerektiğini] cevap olarak söyle!

Eğer ok gezi, ahşabın baş tarafına mı yoksa uç (son) tarafına mı yapılmalı diye sorarlarsa, [ok gezi] ahşabın uç (son) tarafına [yapılır]; temren ise ahşabın baş tarafına [takılır] diye cevap ver!

Eğer tıraşlanmış [ahşabın] baş ve ucunun nasıl tanınacağını sorarlarsa, [şöyle] cevap ver: Ahşabın ortası, işaret parmağının üzerine koyulup havaya atılır. Uçlardan hangisi ilk önce yere meylederse, o taraf ahşabın uç (son), diğeri [ahşabın] baş tarafıdır. Baş kısmın da yere önce meyletmesi hâlinde gönül bununla (bu yöntemle) rahat etmediyse, o hâlde [şöyle] cevap ver: Zikredilen ahşap bir süre durgun suyun üzerine bırakılır. Suda ilk batan kısım, ahşabın uç (son) tarafi olarak bilinmelidir.

Ustalar okun kalitesinin (sahiciliğinin) temrenden geldiğini söylemişler. Temren [oka] sağlam yerleştirilmelidir. [Okçular için] kolların bazısı uzun, bazısı kısa olduğundan dolayı ${ }^{8}$ okun uzunluğu, bir ölçüye mahsus değildir. Bu durumda her kişinin [yay çekerken] işaret parmağı ucu [ile] omuz düşmeksizin kolu uzatıldığında [bir ölçü] meydana gelir. [Bu] o kişinin ok [uzunluk] ölçüsüdür. Ok, bu ölçüden uzun olamaz. Çünkü [uzun] ölçüyü çekene kadar okçunun kuvveti tükenir. Eğer okun fazlalığı (uzunluğu) güçlükle çekiliyorsa, [bu oku] diş temizlemekte [kullanmaya] hiç kuşku olmaz . Yorgun iken [yay] çekildiğinde tutma ve hedef almada muktedir olunmaz. Bakmak (görmek), sabretmek, [ok] atmak ve aynı şekilde yorulmamak, okçulukta büyük marifettir. Eğer ok [hedefe] batmadiysa, [bu eylemlerin] hepsi eksiktir.

Ok, yayın ölçüsüne göre yapılmalıdır. Yaylar uzun ve kısa olurlar. Her ok, her yaya denk gelmez.

Yay ile ok ölçüsü almak şöyledir: Kirişe takılan ok, bulunduğu yerden kabzaya ulaştırılır. [Yayı tutarken] işaret parmağının üç boğumunun koyulduğu yerden (فرجه) orta parmağın son boğumuna kadar sol el kabzaya yerleştiğinde, oluşan mesafe işaretlenerek ölçü alınır. Böylece her ok, bu yöntemle her yaya uygun gelir. Ok, o (ölçüldüğ̈̈) yayın olur.

Ok duası olan yâ selhûsâ (يا سلخوثا) kelimesini okun üzerine yazarlar.

\section{Okçuluk Kuralları}

\section{a) Yaya Kiriş Takmak}

Okçunun öğrenmesi gereken ilk şey, yaya düzgün bir şekilde kiriş takmaktır. [Kiriş takmak için] ustalar her iki dizin, iki kasana yerleştirilmesi gerektiğini söylemişler. Yayın kolları, işaret parmağı üç köşeli boğum yani çekâv-gâh (جكاو كاه) olduğunda avuç ile düzene sokulur. Böylece yay, kirişe ulaşır. [Kiriş] kabza karşısından tat (zevk) verir. Tada (zevke) ulaşmanın şartı, [yayın kollarını, işaret parmağ1] üç köşeli boğum olduğu zamandan çok kaldırmamaktır.

8 Burada yay çekme anında kolların aldığı pozisyondan bahsedilmektedir. Bu pozisyonda kolların uzunluğu ve kısalığı kişiden kişiye farklılık gösterdiği için okun uzunluğunun belli bir ölçüsü yoktur.

9 Yani çekişe mani olan, gereğinden fazla uzun yapılmış ok, ancak diş temizlemekte kullanılır. Atış için uygun değildir.

10 Kelimenin anlamı bulunamadı. 
Ok fırlatanın mertebesi yay çekenden yükssektir. Ustalar yay çekeni ok fırlatanın lütfu [olarak] söylemişler.

\section{b) Okçuluk Mahalinde Durmak}

Ustaların açıklamasına göre okçu, sol ayağı öne koymalı, sağ ayağı arkada dayanak yapmalı ve [iki ayak arasında] bir adım mesafe bırakmalıdır. Sol ayağın topuğu sağ ayağın tabanına karşılık gelmelidir. Dayanak, sağ ayağın üzerinde olmalıdır. Sağ kalça, bel eğilene kadar bir miktar geri götürülmelidir. [Bel] eğme yöntemi, belin bükülmesi ile olur.

\section{Şiir}

Senin okun yola baş koyduğunda,

Biraz beli bük ve her iki omuzu yatır.

\section{c) Kabza Tutmak}

Ustalar kabza tutmanın birkaç türü olduğunu söylemişler:

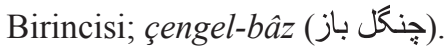

İkincisi; Behrâmî (بهر (برامى)

Üçüncüsü; murebbe " / kare, dört köşeli (مربع) ki, ona gord-moşt (كَرد مشت) da derler.

Çengel-bâz, başparmak ve işaret parmağının birbirinden ayrı olmasıdır. İşaret parmağının tırnağının başı, yayın kabzasının arkasındadır.

Kabza-yi Behrâmî, yay kabzasını sıkıca [kavramış] başparmağın kökünün yukarısından avuca [doğru] serbest ve eğik bir şekilde sokulan parmakların sağlamlaştırılmasıdır.

Murebbe', işaret parmağı ile başparmağın yan yana olmasıdır.

Eğer kiriş üzerinden başparmağı kaldırdığında kol baldırının yaralanmasına ne sebep olur diye sorarlarsa, üç şeyden olur diye cevap ver:

Birincisi; yay kabzasını avuçta tutarsa.

İkincisi; yayı üst taraftan sola doğru meylederek tutarsa.

Üçüncüsü; sağ el ile ok atan kişi sol elle ok atmaya kalkışırsa.

İyi nitelikte kabza tutmanın birkaç delili olur:

Birincisi; kabza tutmada avuç bükme ve su toplaması (uçuk) olmaz.

Bir diğeri; orta, yüzük ve serçe parmağının başının dayanağı, tutuş sağlamlaşana kadar kabza üzerinde olur.

Bir diğeri; başparmak ve işaret parmağı [yay üzerinde] gevşek bulundurulur ve kabza, hendân (خندان) tutuş tarzı ile kavranılır.

Hendân (خندان) tutuş tarzı, baş ve orta parmağın arasının açılması şeklindedir. Şöyle ki; kabza

11 Behrâmî kelimesiyle avlanmayı çok seven ve av sahneleriyle minyatür, kabartma ve tasvirlere konu olan Sâsânî hükümdarı Behrâm-i Gûr (420-438)'a atıf yapılmıştır. Detaylı bilgi için bkz. Nimet Yıldırım, Fars Mitolojisi Sözlüğ̈̈, İstanbul 2017, s. 170-172. 
[iki parmağın] arasından belirir. Bu iş, işaret parmağının başı, orta parmağın ortasının üzerine kapandığında meydana gelir. Kuvvetin tümü, başparmak köküne [ve] boş avuç içine bırakılır. [Tutuşun ölçüsü], yumurta avuç içine koyulursa zarar görmeyecek şekildedir. Başparmak ile yumruk sağlam olur.

Başparmak ve yumruğun sağlamlığı, yayın çekilmeye başlamasından ok atmaya kadar yerinde olur ve kımıldamaz. Başparmak, orta parmaktan yüksek olmamalıdır. Eğer [başparmak orta parmaktan] yüksek ise, [yayın] tutuşu gevşek olur.

Usta üç şeyin sert (sıkı), üç şeyin gevşek, üç şeyin yumuşak, üç şeyin doğru (düz) olması gerektiğini söyler. Başka bir üç [şey ki], çift [hâlde] muktedir olur. Açıklaması:

Üç şey sert olmalıdır: Birincisi yayı tutma; ikincisi oku tutan elden serçe, yüzük ve orta parmak; üçüncüsü sol ayağın ok atış zamanında yere sağlam basmasıdır.

Üç şey gevşek olmalıdır: Birincisi başparmak; ikincisi işaret parmağı; üçüncüsü ok gezinin üzerine işaret parmağı koymaktır.

Üç şey yumuşak olmalıdır: Sol karın (böğür), sol ayak ve başparmak ile işaret parmağıdır.

Üç şey doğru (düz) olmalıdır: Boy, alın ve dirsektir.

Başka üç şey, çifttir ve birlik olmalıdır: Her iki karın (böğür), her iki göz ve her iki el.

Yay elde, su [yayın] üst tarafından döküldüğünde, [yayın] alt tarafına akmayacağı şekilde tutulmalidir.

\section{d) Ok Gezinin Başparmağa Kavuşması Hakkında}

Eğer çûbçe-yi tîr (جوبجهُ تير) yani ok gezinin oka kusur getirmemesi için ne yapılmalı diye sorarlarsa, [şöyle] cevap ver: Ok gezi, kirişin gezin içine oturması için uzun ve geniş olmamalıdır. Giriş yerinde hiç saç teli bulunmamalıdır. Gez, oka düzgün, yuvarlak ve yapışkan olmalı ki [oku] eksiklikten kurtarsın ve [ok] sert saplansın.

Bir okçu dikkatli bir şekilde okçu yüzüğü ile kiriş tutarken, işaret parmağı ve başparmağın kuvveti [ile] getirilen ok gezi üzerinde yumak yapar. İşaret parmağının ucunu başparmaktan geçirir. Kirişi, takılmış okçu yüzüğünün dibinde çeker. Bu yöntem birkaç kusur barındırır:

Birincisi; ok gezinin [üzerinde elin] yumak olmasından üç kusur meydana gelir. Onlardan birisi; [atış esnasında] ok kıpırdar. İkincisi; [ok] gevşek gider. Üçüncüsü; ok gezi kırılır.

Başparmağın tırnağından geçen işaret parmağının ucu, kendi yerinde kalmaz. Ok atış zamanında usta, işaret parmağının ucunu eşek tekmesi [olarak] tokat yemiş kirişin kulağına fisıldar.

Okçu yüzüğü dibinde kiriş tutmada da kusur[lar] hasıl olur: Birincisi; kirişin orta yerinde kopma olur. İkincisi; okçu yüzüğü parmaktan çıkar. Üçüncüsü; ok titrek ve gevşek gider.

En iyi [gez tutuş] yolunu eski ustalar söylemişler ve tecrübe etmişler: İşaret parmağının ucu, başparmak tırnağının üzerine şu şekilde koyulur ki işaret parmağının ucu, tırnağın kökünden açık bir şekilde hilâl gibi olur ve başparmaktan geçer. 


\section{Şiir}

Hilâl gibi bağlandı başparmak,

Futûhî çarh yayından zamana bakmak için.

Kiriş, gez serbest olacak şekilde okçu yüzüğü ile tutulur ve kiriş çekilmiş olur. Gezin kertiği, kirişe bağlıdır. Gez, kavuşma yerinde sabitleşinceye kadar bir derece koza gibi olur. [Böylece] ok serbest bir şekilde tutulurken [kirişten] ayrı olmaz. Okçu yüzüğünün ön tarafına takılmış kiriş orta, yüzük ve serçe parmağını son derece çevik tutmuş [hâlde iken] çekilir. Okçu yüzüğünü kavrama zamanında orta ve işaret parmağının ortasında başparmağın tırnağı kesinlikle olmamalıdır.

Yay çekme ve ok atma konusunda, yay uygun şekilde çekilmiş olana kadar birkaç şart vardır: Birincisi; [yay], bir nevi hamurdan saçın yavaşça çekilmesi gibi yumuşak ve sessiz bir şekilde çekilmelidir.

\section{Şiir}

Yaya ilk önce okçu lazım,

Yumuşak bir şekilde çekmek, doğru bir şekilde ok atmak için.

Sonrasında, yeni ve güç [sahibi] gönülden [yay] çekmek, kola bütün heyecan ve coşkuyla hoşluk verir. Her ne kadar yay [çekmek] kol kuvvetiyle olsa da ok atmak gönül kuvvetiyledir. [Bu durum] yay çekme zamanında bütün uzuvları özellikle göğsü sertleştirir.

İkincisi; [yayın] ortası düğümlü (bağlı) olmalıdır.

Üçüncüsü; [yay] yüz yüze (karşı karşıya) çekilmemelidir.

[Yay çekerken] sağ dirsek bükük, sol dirsek düz ve sağlam bulunur. [Ustalar] bu şekilde söylemişler.

\section{Şiir}

Sol dirsek sağlam durdu, sağ dirsek büküldü,

Çâçi çarh yayından kiriş sesi koptu.

Bir kişi [oku] atmadıysa yay çekme zamanından ok atmaya kadar [yayı tutan] el, dirsek, okçu yüzüğü ve temren düz (doğru) olacak şekilde bulunur. Böylece ok düz gider.

Yay çekmenin marifeti dört tanedir:

Birincisi; doğru bulunmak.

İkincisi; doğru çekmek.

Üçüncüsü; [yayın] kollarını beraber çekmek.

Dördüncüsü; yumuşak çekmek.

Yay çekmenin kusurları çoktur: 
Birincisi; eğri çekmek.

İkincisi; aceleyle çekmek.

Üçüncüsü; yukarı ve aşağı çekmek.

Dördüncüsü; bir kasanı diğer kasandan fazla çekmek.

Beşincisi; yayı kımıldatmak.

Altıncısı; göğsü dışarı çıkarmak.

Yedincisi; olması gerekenden fazla çekmek.

Okçunun iyi [yay] çekmesinin birkaç tarzı vardır:

Birincisi; [yayı] tutma sıkıca olur. Üç parmak [yayın üzerine] sağlam yerleşir. Sert tutulmuş boyun, okçunun vücudundan [geriye doğru] çekilir. Süratli bir şekilde ok atılır ve sol ayak sabit kalır.

Bir diğeri; okçu yüzüğü, ok geçirme zamanında dirsek düz iken tutulur.

Bir diğeri; yay çekmeyi ustalar üç çeşit olarak söylemişler. [Bu konuda] şair şöyle demiş:

\section{Şiir}

[Yayı] kaştan ve sineden çekendir [yayı] bıyıktan çeken,

[Yayı1] kaş ve sineye koyar, [yayı1] bıyıktan çeken ${ }^{12}$.

Ancak en iyi çekiş, bıyık hizasından çekilmiş [yayın] kulak memesinden geçmesiyle oluşur. Okçu, yay çekme zamanında omuzlarını kaldırmamalıdır. Sol el, okçunun direğidir ${ }^{13}$. Kol gövdesi ile pazı, dirsek ve başparmak uyum içinde tutulmalıdır. Bu tutuş kaliteli olmazsa, okçu çaresiz [bir şekilde] maksadından mahrum kalır ${ }^{14}$.

Yay çekme vaktinde uzuvlar beş hususta çok sıkı bulunur:

Birincisi; [yay çekerken] göz oynamaz.

İkincisi; karşı karşıya [yay] çekilmez.

Üçüncüsü; [yay çekerken] başın üstündeki su dolu tastan bir damla dökülmeyecek derecede dahi baş kımıldamaz.

Dördüncüsü; [yay çekerken hedeften] başka yere bakılmaz.

Beşincisi; [yay çekerken] el tutuşu, sağ bacak, sol ayak ve bel kıvrımı sağlam ve sabit olur.

\section{Şiir}

[Oku] yaya koyma ve atma, demir koruyucu gibidir,

Biraz beli bük ve her iki omuzu yatır.

Eğer yay çekme zamanında kiriş ne kadar bükülmeli diye sorarlarsa birkaç cevap ver: Yay iki hisse, kiriş bir hisse [bükülür]. Çünkü yay eğri, kiriş düzdür. Bu sebeple yay bir hisse fazla bükülür.

12 Dizeye göre yay çekme çeşitleri; ebrû-keş (kaştan çeken), sîne-keş (sineden çeken) ve burût-keş (biylktan çeken).

13 Okçu yay çekerken sol el, direk gibi düz ve sağlam olmalıdır.

14 Yani yay çekerken kolun gövde, pazı ve dirsek kısmı ile başparmak uyumlu olmazsa, okçu hedefini vuramaz. 
Eğer hedef 400 gez (yaklaşık 380 m.) $)^{15}$ mesafedeyse, ok uygun bir şekilde gidip hedefe düz bir şekilde yönelinceye kadar, yay kuvvet barındırdığında yumruk (avuç) hangi pozisyonda (kaidede) olmalıdır diye sorarlarsa [şöyle] cevap ver: El tutuşunda yüzük parmağı hedefe karş1 olur ve ok atılır. Eğer [hedef için] ölçü 300 gez (yaklaşık 285 m.) olursa, el tutuşunda serçe parmağı hedef üzerine nişan alınır. Hedef, 200 gez (yaklaşık 190 m.) mesafede olduğu zaman orta parmak hedefe denkleşir. Eğer hedef 100 gezde (yaklaşık 95 m.) olursa, işaret parmağ 1 ve ok temreni kalp üzerinden nişan alınır ve ok atılır. Eğer hedef uzaklığg 100 gezden (yaklaşık 95 m.) az olursa, [okun] hedefe doğru yönelmesi için yumruk (avuç) tutuşu hedeften biraz aşağıya yerleştirilir.

Okun [hedefe] kötü gitmesi birkaç şeydendir: [Birincisi]; organlar gevşektir. İkincisi; okçu uzun boylu, kiriş kalındır. [Üçüncüsü]; ok büyük, yay yumuşaktır.

Eğer ok [yay çekerken] nereye kadar getirilmeli diye sorarlarsa, kabzaya bırakılana kadar düz gelir ve kusur getirmez diye cevap ver!

Eğer [ok, kabzaya] bırakılma vaktinde kabza sınırından içeri geçerse, misvak olması mümkündür ${ }^{16}$. Bu yüzden başlangıçta yavaşça çekilmelidir. Atik ve çabukluk ile birlikte olan okçunun gücü, temren kabza yakınına geldiğinde, mümkün oldukça daha uygun [bir şekilde] gezi yay koluyla, temreni kabza ile eşit hâlde ok atışı yapar. Buna terimde tîr-endâzî-yi kend derler.

\section{Şiir}

Okunun sert gönülü delip geçmesini istiyorsan,

Karşısında sıçrayarak vur kırbacı,

Başını vuracağın hedefi görüyor musun?

Her iki omuzu yaya eşlik eden o kimse,

Yayı çekip oku atarsa,

Kuvvet ile kirişi ve hedefi süslesin,

Kedi yay burcunda, aslan mutlu olduğunda,

Başkentte ok atma vakti yiğitlerle ovada.

[Oku] bırakma zamanında her iki el, arkaya götürülmelidir. Sanki sağ el, habersizce yakıcı ve sıcak yemeğe temas etmiş gibi olmalıdır. Keskinlik ve sıcaklıkla geriye götürülmüş sağ elin çekilmesiyle, okçunun sol elinden sanki birisi yayı rica etmiş gibi olmalıdır. Haberci ansızın bu konudan sürat ve çabukluk ile [okçuyu] haberdar etmiş [gibi] sol el, avucuyla arkaya götürülmelidir. Temren kabza ortasına vardığı zaman çekiş yapılmalıdır.

15 Gez uzunluk birimi, tarihte İran'da kullanılan önemli uzaklık ölçülerinden biriydi. XVII. yüzyılda İran'da gez-i şâhî ortalama 95 cm.'ye eşitti. Detaylı bilgi için bkz. Walther Hinz, İslâm'da Ölçü Sistemleri, Türkçe terc. Acar Sevim, İstanbul 1990, s. 76.

16 Kullanılan okun, okçuya göre olmadığı ve işe yaramayacağı belirtiliyor. 
Ustalar temreni düşman [olarak] söylemişler. Düşmanı kasan bölgesine geçirmek bilgelikten uzaktır. Ama maharet sahibi ustalardan bazıları, kabza içine geçmiş temreni, bilek siperi başından atmanın büyük bir hüner olduğunu söylemişler. Ünlü okçuların kasanda gömülmüş oku, bilek siperi başıyla attıkları görüldü.

[Kirişi] çektikten sonra [okun] geriye gitmemesi yani misvak olmaması için ihtiyat gerekir.

Eğer yumruk ve okçu yüzüğü iyi tutulmuş [olmasına rağmen] ok niçin titrek gider ve bıyık-sakal kılı ne sebeple incinir diye sorarlarsa [şöyle] cevap ver: Çünkü yay kuvvet yüklü olur. Her [ok atış] tarzı, sol yay koluna aşağı meyilli yapılır. İşaret parmağı ve başparmak, gez üzerine hükmederek baskı getirir. [Buradaki] tehlike gezin kırılmasıdır. Eğer gez kırılmazsa, ok yayın iç kısmına eğik [bir şekilde] geçer ve ok atma vaktinde kasan parçası kırılır. Eğer kırılmazsa, ok titrek ve başıboş [bir şekilde] gider. Kiriş, bıyık-sakal kılını kapar. Yay kendi güç dengesiyle olduğunda ve başparmak doğru tutulduğunda, elbette sağ yay koluna meyil [olur] veya her iki el açılır. O zaman ok, kusurdan kurtulur. Bıyık-sakal kılı kirişten zarar görmez. Okçunun kuvvetiyle yayın [çekiş gücü] 12 menn (yaklaş1k 10 kg.) $)^{17}$ 'e denk olur. Öncelikle ileri gelenler, [çekiş kuvveti] 10 menn (yaklaşık 8 kg.) olan yayı, ok sanatı boyunca [atış] görünümünün yerine getirilebilmesi ve yay çekerken kirişin sakala ulaşmaması maksadıyla doğrulanabilmesi için ele alırlar ${ }^{18}$.

Bir okçunun hünerinin tamamı, nefesini ok atışı sırasında çekmemesidir. [Ok] batana kadar [nefesini] tutar. Ok atıldığı zaman soluğunu [okun] rüzgârıyla gönderir.

\section{e) Hedefe Bakmak}

Okçunun töresi hedeftir. Usta, ilk önce temrene bakılması gerektiğini söyler. İyi nişan almadan hedefe ok atılmaz.

\section{Şiir}

Başparmak ile ok gezini kavradığında [hedefe] bak!

[Oku] elden firlatmak için.

Eğer ok atma vaktinde nereye bakılır ve ok uygun bir şekilde gidene kadar göz nereye döndürülür diye sorarlarsa, [şöyle] cevap ver: İki göz de kabza ve ok yoluna doğru hedef üzerinde bulunur. Göz, hata etmez. Hata etmek de kusurlardandır.

Yörünge merkezi gibi olan gözün, [yay] çekme vaktinden ok atıncaya kadar, hedef üzerine dikilmesinin [söylenmesi] doğru bir sözdür. Hedefin arkasındaki hiçbir şey göze takılmamalıdır.

17 Menn ağırlık birimi, tarihte İran coğrafyasında kullanılan önemli ağırlık ölçülerinden biriydi. Küçük menn (833 gr.), orta menn (1920 gr.) ve büyük menn (3 kg.) şeklinde tasnif edilmişti. Hesaplamalar küçük menn'e göre yapılmıştır. Ayrıntılı bilgi için bkz. Walther Hinz, İslâm'da Ölçü Sistemleri, s. 21-22; Cengiz Kallek, "Men”, DİA, XXIX, (2004), s. 105-107.

18 Burada usta okçuların atış pozisyonu ve sakala zarar vermeden doğru yay çekiş tarzları hakkında tecrübesiz okçulara bilgi verdiklerinden bahsedilmektedir. 
Okçunun ilk bakışı, hedeften başka hiçbir yere olmamalıdır. Gözün baktığı yere mutlaka gönül de gitmelidir. Göz birliği ve iddialı gönül sayesinde hedefi vurma sonuçlanmalıdır. Hedefe bakmak birkaç türdür. Şöyle ki; Cagtiye (جغتيه) oymağından biri olan Cet (جت) kavmi, kabza dışından [hedefe] bakar. Tâhir-i Belhî [bu durum için]; "eğer kabza ortasında delik olsaydı oradan [hedefe] bakarlard1. Daha iyi olurdu" der.

Hindistan halkının muteber ساز نكدر هر بر جا kitabından, eğer kabzayı tutan yumruk ile denklenmiş hedefe ok atılırsa, elbette işin oluruna yakın ve hatadan uzak olunacağını naklederler.

Yayı kurma işleminin vasıfları şunlardır: [İşaret parmağının] üç köşesinin (ekleminin) [yay kolu üzerinde] koyulduğu yere furce (فرجه) derler. Furce denilen yerde [yayın kolunu bükerken işaret parmağı] üç köşeli boğum olur. Buna çekâv-gâh (جكاو كاه) derler. Ona yakın olan kasanı sîne (سينه); kasandan daha aşağıda kabza yakınında olan yeri hizâne (خز كزانه) olarak adlandırırlar. Kabzayı avuca alırlar. Kabzanın tutulduğu yerden ok [ile] nişan alırlar. Buna seyfeh / sîfeh (سيفح) derler. Kabzanın diş tarafina kefâf (كفاف) da derler.

Ovada uzak hedef, yakın görünür. Duvardaki alçak / kısa hedef, uzak görünür.

Teșekkür: Tercüme süresince sorularımı içtenlikle cevaplayan Dr. Ali Riza Mukaddem'e teșekkürü borç bilirim.

Hakem Değerlendirmesi: Dış bağımsız.

Çıkar Çatışması: Yazar çıkar çatışması bildirmemiştir.

Finansal Destek: Yazar bu çalışma için finansal destek almadığını beyan etmiştir.

Peer-review: Externally peer-reviewed.

Conflict of Interest: The author has no conflict of interest to declare.

Grant Support: The author declared that this study has received no financial support.

\section{Kaynakça/References}

[Fahr-i Mudebbîr, Âdâbu'l-Harb ve'ş-Şecâ'a, neşr. Ahmed Suheylî-yi Hânsârî, Tahran 1346/1967.

Hinz, Walther, İslâm'da Ölçü Sistemleri, Türkçe terc. Acar Sevim, İstanbul 1990.

Kallek, Cengiz, “Men”, DİA, XXIX, (2004), s. 105-107.

Karpowicz, Adam, Osmanlı Türk Yayları İmali ve Tasarım, Türkçe terc. Mehmet Yılmaz Akbulut, İstanbul 2018.

Şucâ'u'd-dîn Dorûd-bâşî-yi Beyhakî, “Câmi’u'l-Hidâyet fî 'İlmi’r-Rimâyet”, neşr. Muhammed Takî Dânişpejûh,

Ferheng-i İrân-zemîn, XI, (1342/1963), s. 229-280; Okçuluk Sanatı, Türkçe terc. İbrahim Duman, İstanbul 2020.

Yıldırım, Nimet, Fars Mitolojisi Sözlüğ̈̈, İstanbul 2017.

Yücel, Ünsal, Türk Okçuluğu, Ankara 1999]. 